\title{
Influence of inoculum activity on the bio-methanization of a kitchen waste under different waste/inoculum ratios
}

\author{
L. Neves, R. Oliveira, M.M. Alves* \\ Centro de Engenharia Biológica, Universidade do Minho, 4710-057 Braga, Portugal
}

Received 2 June 2003; received in revised form 1 August 2003; accepted 12 October 2003

\begin{abstract}
The use of a granular inoculum prevented acidification during the anaerobic batch biodegradation of a kitchen waste for waste/inoculum ratios in the range of $0.5-2.3 \mathrm{~g}$ VS/g VS, when the alkalinity/COD ratio was $37 \mathrm{mg} \mathrm{NaHCO} / \mathrm{g}$ COD. In similar experiments but using a suspended sludge with a significantly lower activity, the methane production rates and the biodegradability were significantly lower and the $\mathrm{pH}$ decreased below 5.5 at the waste/inoculum ratio of $2.3 \mathrm{~g} \mathrm{VS} / \mathrm{g}$ VS. When the added alkalinity was decreased to $2 \mathrm{mg} \mathrm{NaHCO} / \mathrm{g} \mathrm{COD}_{3}$ the ratio waste/inoculum was clearly more important than the inoculum activity, since, irrespective of the sludge used, acidification occurred at waste/inoculum ratios higher than $0.5 \mathrm{~g} \mathrm{VS} / \mathrm{g}$ VS. The advantage of using granular sludge was further investigated in order to define reasonable condition of waste/inoculum ratio and added alkalinity that could be applied in practice. For a waste/inoculum ratio of 1.35 , there were no significant differences between the results obtained for the biodegradability and maximum methane production rate (MMPR), when the alkalinity decreased from 44 to $22 \mathrm{mg} \mathrm{NaHCO}_{3} / \mathrm{g} \mathrm{COD}$.
\end{abstract}

(C) 2003 Elsevier Ltd. All rights reserved.

Keywords: Anaerobic bio-methanization; Granular sludge; Suspended sludge; Kitchen waste; Waste/inoculum ratio; Alkalinity

\section{Introduction}

In order to reduce uncontrolled methane emissions, odour nuisance and leachate production, European policies for environmental protection are imposing severe restrictions to the landfilling of non-stabilized organic refuse. Kitchen waste is a typical biodegradable organic waste suitable for controlled anaerobic digestion.

Mineralization of a solid waste through the anaerobic digestion process requires the co-ordinated action of different bacterial trophic groups, so as to prevent local accumulation of intermediates which can be potentially inhibitory. The complexity of waste/seed interactions is expected to increase with the solid content of the waste to be digested. A model for the anaerobic solid-state fermentation was developed by Kalyuzhnyi et al. [1], which considers two particles in the process: seed particles with high methanogenic activity and low biodegradability and waste particles with

\footnotetext{
* Corresponding author. Tel.: +351-253-604-402; fax: +351-253-678-986.

E-mail address: madalena.alves@deb.uminho.pt (M.M. Alves).
}

low methanogenic activity and high biodegradability. For a one-stage batch process, the crucial point is to prevent volatile fatty acids accumulation inside the "seed" particles beyond their assimilative methanogenic capacity [1]. This can be accomplished by increasing the amount of seed sludge, in order to overcome irreversible acidification during start-up [2]. The waste/inoculum ratio is then an important parameter in batch high solid anaerobic digestion processes as well as in the assessment of anaerobic biodegradability of solid wastes. The use of a large inoculum amount in a batch process allows a successful digestion without $\mathrm{pH}$ adjustment, being a value of 1 (VS basis) usually used in the assessment of the biochemical methane potential (BMP) [3]. However, in the case of more recalcitrant wastes, the rate of methane production in BMP assays was optimized by decreasing the waste/inoculum ratio to $0.5 \mathrm{~g}$ VS/g VS [4]. Although typical values are indicated for the required amount of inoculum, little attention is usually devoted to the influence of inoculum activity. It is expected that for the assessment of the anaerobic biodegradability of a solid waste, the use of a highly active anaerobic sludge will reduce significantly the time of the experiment. On the other hand, for the start-up 
of full scale batch digesters, the use of an active sludge can significantly reduce the amount of inoculum required and, consequently, the corresponding digester volume.

The aim of the present work was to evaluate the influence of the sludge activity in the anaerobic biodegradation of a real kitchen waste at waste/inoculum ratios between 0.5 and $2.3 \mathrm{~g} \mathrm{VS} / \mathrm{g} \mathrm{VS}$, for alkalinity/COD ratios of 2 and $37 \mathrm{mg} \mathrm{NaHCO} / \mathrm{g}$ COD. A suspended sludge and a granular sludge with a significantly higher methanogenic activity, were compared. The need for $\mathrm{pH}$ control in the tested conditions is discussed and additional assays with granular sludge at a waste/inoculum ratio of 1.35 and added alkalinity in the range of $0-44 \mathrm{mg} \mathrm{NaHCO}_{3} / \mathrm{g} \mathrm{COD}$ are presented.

\section{Materials and methods}

\subsection{Kitchen waste}

The kitchen waste was a composed sample (1 week based) from the waste produced in the restaurant of the University of Minho, located in Campus de Gualtar, Braga. It had the following characteristics: total solids (TS) $=23.8 \pm 1.4 \%$; volatile solids (VS) $=21.4 \pm 0.7 \%$; chemical oxygen demand $(C O D)=1370 \pm 307 \mathrm{mg} / \mathrm{g}$ TS waste; total Kjeldahl nitrogen $(\mathrm{TKN})=55.9 \mathrm{mg} \mathrm{N}-\mathrm{TKN} / \mathrm{g}$ TS waste; fat content $=84 \mathrm{mg}$ fat $/ \mathrm{g}$ TS waste.

\subsection{Inoculum}

The granular sludge was collected from an UASB reactor treating a brewery effluent located in Oporto, Portugal. The suspended sludge was collected from a local municipal sludge digester. The specific methanogenic activity in the presence of acetate, propionate, butyrate and $\mathrm{H}_{2} / \mathrm{CO}_{2}$ is presented in Table 1 for both sludges.

\subsection{Batch experiments}

\subsubsection{Activity measurements}

Methanogenic activity tests were performed using a pressure transducer technique [5]. The test involves the monitoring of the pressure increase developed in sealed vials fed with non-gaseous substrates or pressure decrease in vials previously pressurised with gaseous substrates $\left(\mathrm{H}_{2} / \mathrm{CO}_{2}\right)$. Strict anaerobic conditions were maintained, us- ing an anaerobic basal medium composed of cysteine- $\mathrm{HCl}$ $(0.5 \mathrm{~g} / \mathrm{l}), \mathrm{NaHCO}_{3}(3 \mathrm{~g} / \mathrm{l})$, with the $\mathrm{pH}$ adjusted to 7.0-7.2. Rezasurin was added as an indicator of redox potential. This basal medium was prepared by boiling the medium before adding the bicarbonate. When the pink colour of rezasurin disappeared, indicating that suitable anaerobic conditions were achieved, it was left to cool down under a continuous flow of $\mathrm{N}_{2}$ in the headspace. Then, the bicarbonate was added, the gas was changed to a mixture of $\mathrm{N}_{2} / \mathrm{CO}_{2}$ (80:20, $\mathrm{v} / \mathrm{v})$ and finally it was dispensed to the vials avoiding the contact with air. The hand held pressure transducer used was capable of measuring a pressure increase or decrease of two atmosphere $(0 \pm 202.6 \mathrm{kPa})$ over a range of -200 to $+200 \mathrm{mV}$. The sensing element is connected to a digital panel module and the device is powered by a $9.0 \mathrm{~V}$ dc transformer. All activity tests were performed in triplicate. The volume of methane produced was corrected to the standard temperature and pressure (STP) conditions.

\subsubsection{Biodegradation experiments}

Biodegradation experiments were performed in vials of $160 \mathrm{ml}$. Four waste/inoculum ratios were tested using the two sludges: $0.5,1.0,1.35$ and $2.3 \mathrm{~g}$ VS waste/g VS inoculum. In a first run of experiments, the initial ratio alkalinity/COD was set at $37 \mathrm{mg} \mathrm{NaHCO} / \mathrm{g} \mathrm{COD}$. In order to understand the influence of inoculum activity on the need for $\mathrm{pH}$ control, a second run of experiments was done, with an initial alkalinity/COD ratio of $2 \mathrm{mg} \mathrm{NaHCO}_{3} / \mathrm{g}$ COD. A third run of experiments was done with granular sludge at a waste/inoculum ratio of 1.35 and three values of added alkalinity: 0, 22 and $44 \mathrm{mg} \mathrm{NaHCO}_{3} / \mathrm{g} \mathrm{COD}$. The alkalinity was adjusted by adding a defined volume of the anaerobic basal used in the activity measurement assays. The waste and the sludge were placed in the vial and the basal medium was dispensed avoiding the contact with air. The vials were then incubated at $37^{\circ} \mathrm{C}$ under stirring conditions $(15.7 \mathrm{rad} / \mathrm{s})$ and the pressure increase was monitored by the above-mentioned pressure transducer device. At regular time intervals, the vials were depressurised and the biogas composition was analyzed for $\mathrm{CH}_{4}$ and $\mathrm{CO}_{2}$ content. Biodegradability tests were performed in duplicate assays.

The maximum methane production rate (MMPR), was always considered as the slope of the initial linear part of each curve of methane production versus time. The term "biodegradability" was defined as the maximum plateau achieved in the methane production curves after $600 \mathrm{~h}$

Table 1

Specific methanogenic activity of the granular and suspended inocula

\begin{tabular}{lccccc}
\hline & \multicolumn{4}{l}{ Specific methanogenic activity $\left(\mathrm{ml} \mathrm{CH} \mathrm{CH}_{4}(\mathrm{STP}) / \mathrm{g}\right.$ VS waste per day) in the presence of } \\
\cline { 2 - 5 } & Acetate & Propionate & Butyrate & Ethanol & $\mathrm{H}_{2} / \mathrm{CO}_{2}$ \\
\hline Granular sludge & $343.7 \pm 69.7$ & $167.3 \pm 16.7$ & $69.4 \pm 8.9$ & $663.0 \pm 78.5$ & $1029 \pm 14$ \\
Suspended sludge & $45.5 \pm 1.1$ & $2.6 \pm 0.7$ & $31.3 \pm 0.2$ & $54.4 \pm 3.9$ & $93 \pm 6$ \\
\hline
\end{tabular}

STP: standard temperature and pressure conditions. 
from the first pressure reading - set as the initial time of the assay-divided by the amount of waste COD initially present in the vial.

The methane production due to biomass decay and due to the possible presence of residual substrate was discounted by performing blank controls. Both the MMPR and the maximum plateaux were corrected. For the granular sludge, the MMPR and the plateau were, respectively, $6.67 \pm 1.35 \mathrm{ml}$ $\mathrm{CH}_{4} / \mathrm{g}$ VS sludge per day and $16.93 \pm 2.14 \mathrm{ml} \mathrm{CH}_{4} / \mathrm{g}$ VS sludge, and for the suspended sludge the MMPR was $10.45 \pm 1.42 \mathrm{ml} \mathrm{CH}_{4} / \mathrm{g}$ VS sludge per day and the plateau was $50.12 \pm 9.41 \mathrm{ml} \mathrm{CH}_{4} / \mathrm{g}$ VS sludge. The volume of methane produced was corrected to standard temperature and pressure conditions.

\section{Analytical methods}

Chemical oxygen demand, volatile and total solids, and total Kjeldahl nitrogen were determined according to Standard Methods [6]. Methane and carbon dioxide content of the biogas were measured by gas chromatography using a Porapack Q (100-180 mesh) column, with He as the carrier gas at $30 \mathrm{ml} / \mathrm{min}$ and a thermal conductivity detector. Temperatures of the detector, injector and oven were 110, 110 and $35^{\circ} \mathrm{C}$, respectively.

\section{Results and discussion}

Fig. 1 represents the methane production curves obtained for the granular and the suspended sludge under different waste/inoculum ratios for the assays with an initial alkalinity/COD ratio of $37 \mathrm{mg} \mathrm{NaHCO}_{3} / \mathrm{g} \mathrm{COD}$.

Fig. 2 compares the maximum methane production rate and the biodegradability obtained in each condition. Granular sludge was significantly more active than suspended sludge, suggesting that the number of active bacteria involved in the acetogenic and methanogenic conversions was much higher in that structured sludge. This can explain the better methane production rates observed with granular sludge. The increase in the relative amount of inoculum was in this case of minor importance as compared to suspended sludge, since the maximum methane production rate and the biodegradability did not change significantly for all the waste/inoculum ratios studied. The slight increase in biodegradability observed in Fig. $2 b$ for the waste/inoculum ratios higher than $1 \mathrm{~g}$ VS/g VS, was not expected, but may likely arise from the high heterogeneity of the real waste.

The increase in the waste/inoculum ratio can lead to overloads due to volatile fatty acid accumulation. If the $\mathrm{pH}$ drops below 6.5, inhibition of methanogenesis can occur. It is expected that a high concentration of active methanogenic sludge can contribute to overcome that inhibition, since the inoculum should be able to process a higher flow of metabolites such as hydrogen, acetate and other VFA, preventing their accumulation. Furthermore, the architecture and spatial arrangement of granular sludge, protects the bacteria located in the inner core (mostly acetoclastic) from adverse environmental conditions prevailing in the bulk medium. The close proximity between the different groups of bacteria in the granular sludge can improve the metabolic flow of intermediates and products, especially the syntrophic transfer of hydrogen from acetogens to hydrogenotrophs. This can,
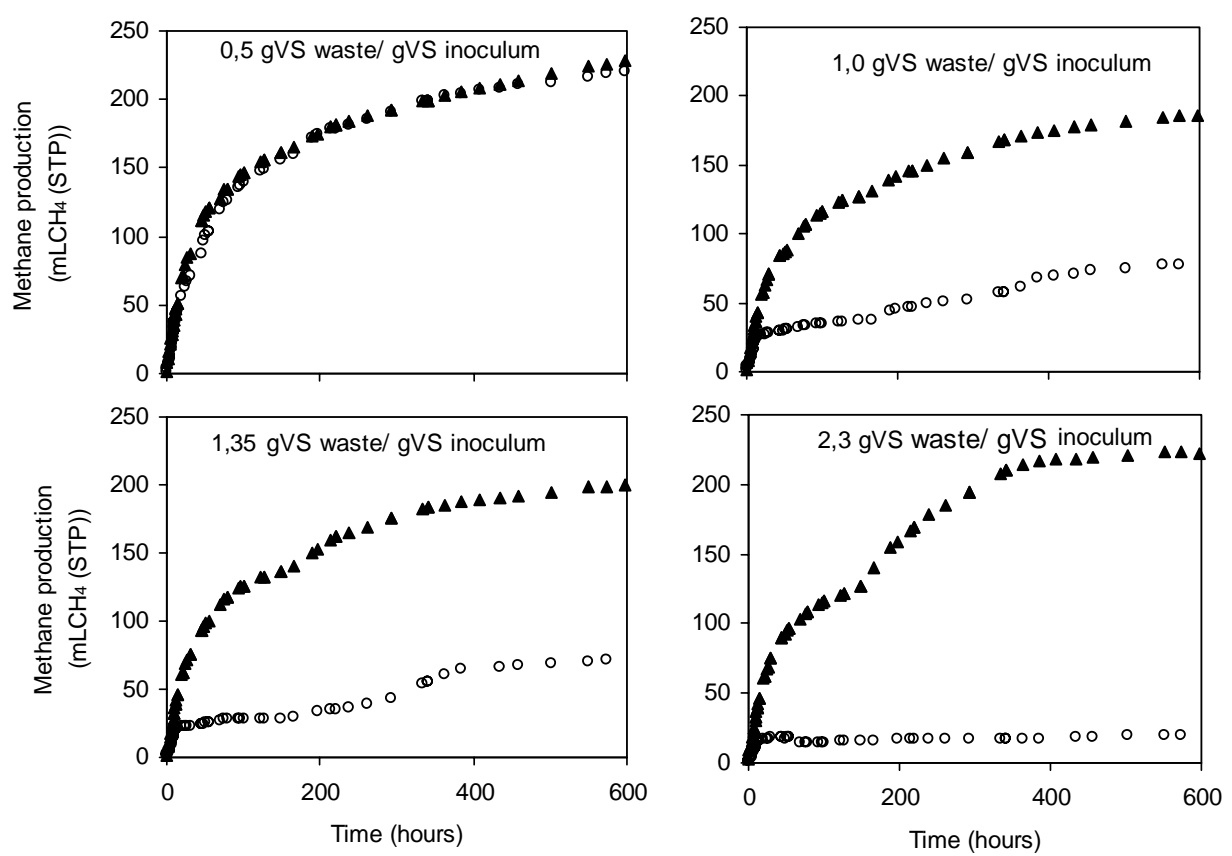

- suspended sludge $\Delta$ granular sludge

Fig. 1. Methane production obtained in the assays at $37 \mathrm{mg} \mathrm{NaHCO} / \mathrm{g} \mathrm{COD}$ using suspended and granular sludges. Influence of the waste/inoculum ratio. In these curves, the residual methane production was not excluded. 

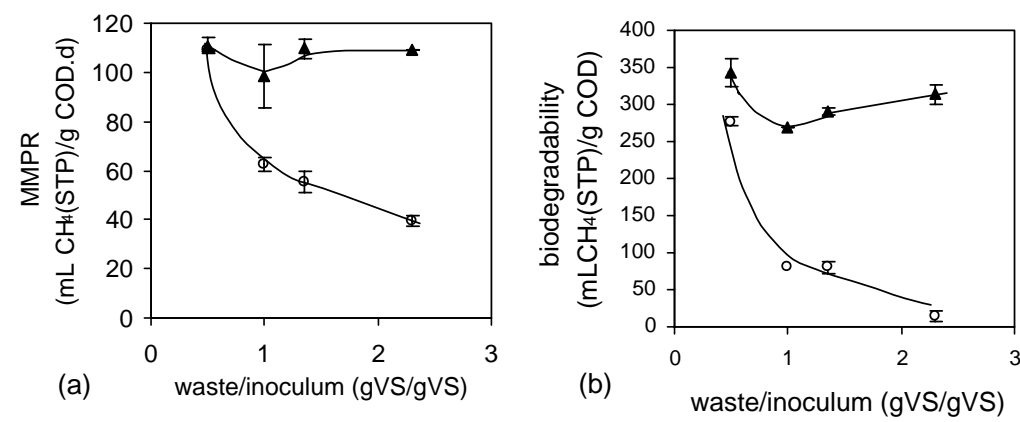

- granular sludge

- suspended sludge

Fig. 2. Maximum methane production rate (a) and biodegradability (b) in the assays at $37 \mathrm{mg} \mathrm{NaHCO}_{3} / \mathrm{g}_{\mathrm{COD}}$ using suspended and granular sludges. Influence of the waste/inoculum ratio. The residual methane production was excluded in these values. The bars represent the standard deviation.

in part, explain the different final $\mathrm{pH}$ values achieved in the vials which dropped to 5.2 in suspended sludge for the assay with $2.3 \mathrm{~g}$ VS waste/g VS inoculum, but remained in the range of 7.02-7.17 for all the assays with the granular sludge.
In order to assess the limits of this behaviour, an assay was run with the two sludges, under the same waste/inoculum ratios and applying an alkalinity/COD ratio of $2 \mathrm{mg}$ $\mathrm{NaHCO}_{3} / \mathrm{g} \mathrm{COD}$. Fig. 3 represents the obtained results and
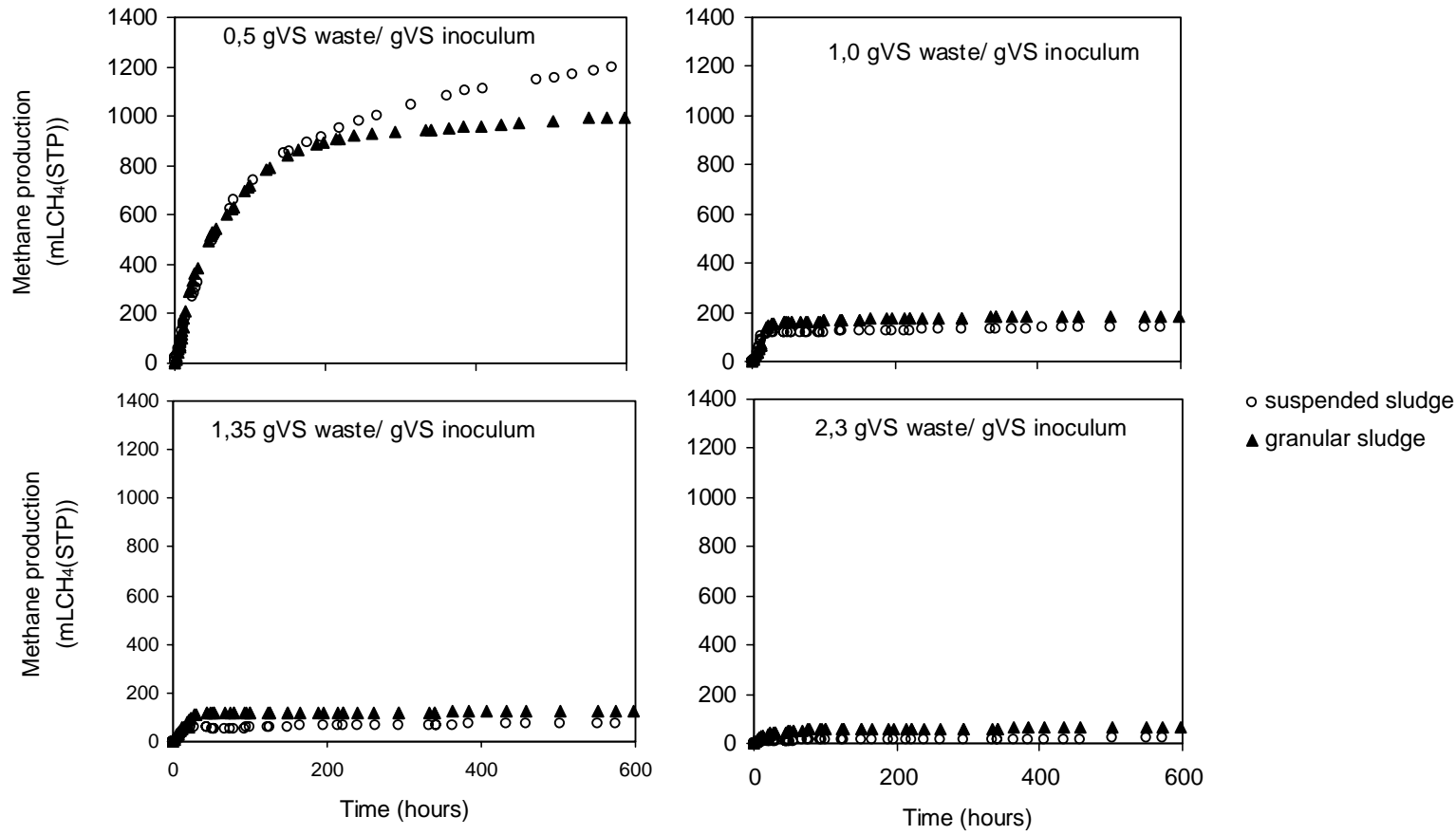

Fig. 3. Methane production obtained in the assays at $2 \mathrm{mg} \mathrm{NaHCO} / \mathrm{g} \mathrm{COD}$, without $\mathrm{pH}$ control, using suspended and granular sludges. Influence of the waste/inoculum ratio. In these curves, the residual methane production was not excluded.
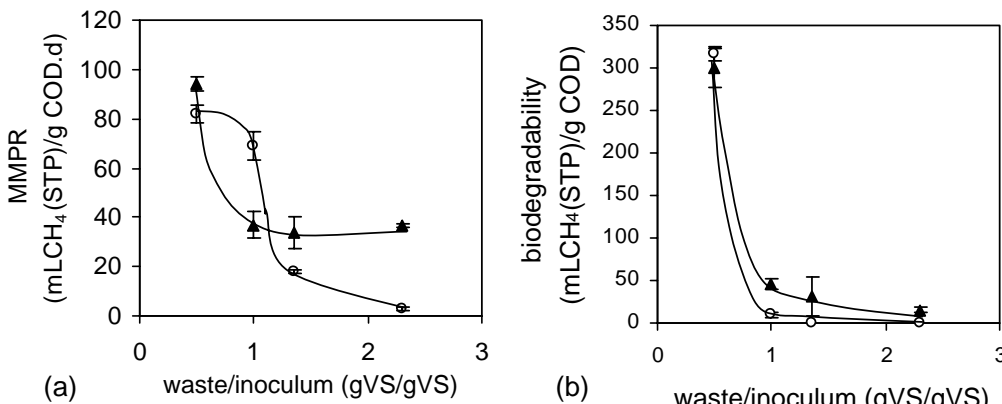

\ granular sludge

- suspended sludge

Fig. 4. Maximum methane production rate (a) and biodegradability (b) in the assays at $2 \mathrm{mg} \mathrm{NaHCO}_{3} / \mathrm{g} \mathrm{COD}$, using suspended and granular sludges. Influence of the waste/inoculum ratio. The residual methane production was excluded in these values. The bars represent the standard deviation. 

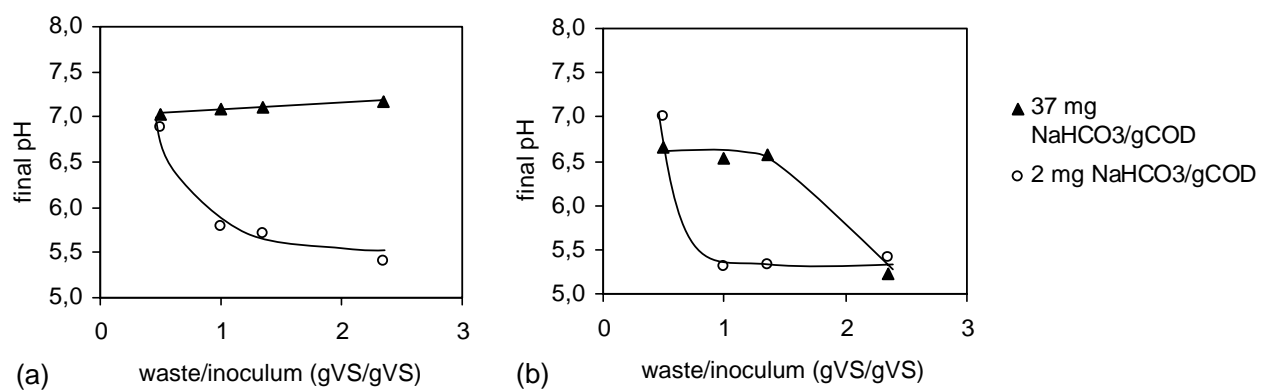

(b)

waste/inoculum (gVS/gVS)

Fig. 5. Final pH values in the assays using granular (a) and suspended (b) sludges. Influence of the waste/inoculum ratio and alkalinity.

Fig. 4 compares the maximum methane production rate and the biodegradability, as defined by the " $600 \mathrm{~h}$ plateaux" achieved in each curve.

In this case, the methanization rate was not significantly higher for the granular than for the suspended sludge. The biodegradability was, for both sludges, maximal for a waste/inoculum ratio of $0.5 \mathrm{~g}$ VS/g VS and decreased sharply when this ratio increased beyond this value. Although this behaviour was similar for both sludges, when using the granular sludge a slightly higher plateau was obtained for all the assays (Fig. 4). Fig. 5 represents the influence of alkalinity/COD ratio on the final $\mathrm{pH}$ achieved in the assays with granular (Fig. 5a) and suspended (Fig. 5b) sludge.

It is clear that the granular sludge prevented acidification for all the tested waste/inoculum ratios, when the amount of alkalinity initially present in the vials was $37 \mathrm{mg} \mathrm{NaHCO} / \mathrm{g}$ COD. However, strong acidification occurred for the assay at $2.3 \mathrm{~g} \mathrm{VS}$ waste/g VS inoculum, when using suspended sludge. A further decrease in alkalinity to a value as low as $2 \mathrm{mg} \mathrm{NaHCO}$ added/g COD, showed that acidification was only prevented for the lowest waste/inoculum ratio being, in this case, the inoculum activity of minor importance. The practical interest of these results is not restricted to the assessment of the anaerobic biodegradability. For a batch operated digester it should be important to define the required amount of inoculum, taking into account the corresponding activity and the need for $\mathrm{pH}$ control. In this context, it was considered interesting to investigate further the potential use of granular sludge, for different alkalinities at a waste/inoculum ratio of 1.35 , which seems to be more reasonable in practical terms than a lower value for instance $0.5 \mathrm{~g} \mathrm{VS} / \mathrm{g}$ VS. Table 2 compares the obtained values of MMPR and biodegradability obtained for added alkalinity of $0,2,22,37$ and $44 \mathrm{mg} / \mathrm{g}$ COD.

The value obtained for the biodegradability when adding $37 \mathrm{mg} \mathrm{NaHCO} / \mathrm{g} \mathrm{COD}$ is somewhat higher than expected, which can be due to the waste heterogeneity. It should be referred that the waste used in the assays at 0,22 and $44 \mathrm{mg}$ $\mathrm{NaHCO}_{3} / \mathrm{g}$ COD was collected in a different week from that used in the two other assays. From the results presented in Table 2, it is shown that the reduction of alkalinity un-

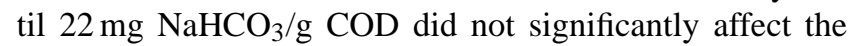
MMPR and the biodegradability, when compared to the values when adding $44 \mathrm{mg} \mathrm{NaHCO} / \mathrm{g} \mathrm{COD}$.
Table 2

Effect of alkalinity on the biodegradability and maximum methane production rate for the kitchen waste at waste/inoculum ratio of $1.35 \mathrm{~g} \mathrm{VS} / \mathrm{g}$ VS

\begin{tabular}{|c|c|c|}
\hline $\begin{array}{l}\text { Alkalinity } \\
(\mathrm{mg} \mathrm{NaHCO} / \mathrm{g} \\
\text { COD) }\end{array}$ & $\begin{array}{l}\text { Biodegradability } \\
\left(\mathrm{ml} \mathrm{CH}{ }_{4}(\mathrm{STP}) / \mathrm{g}\right. \\
\mathrm{COD})\end{array}$ & $\begin{array}{l}\text { MMPR }\left(\mathrm{ml} \mathrm{CH}_{4}\right. \\
(\mathrm{STP}) / \mathrm{g} \mathrm{COD} \\
\text { per day })\end{array}$ \\
\hline 0 & $58.0 \pm 1.2$ & $28.3 \pm 2.2$ \\
\hline 2 & $30.8 \pm 23.4$ & $33.7 \pm 6.4$ \\
\hline 22 & $176.0 \pm 18.6$ & $115.6 \pm 10.6$ \\
\hline 37 & $290.6 \pm 4.6$ & $109.6 \pm 4.0$ \\
\hline 44 & $174.18 \pm 3.5$ & $126.4 \pm 6.0$ \\
\hline
\end{tabular}

STP: standard temperature and pressure conditions.

\section{Conclusions}

In batch anaerobic biodegradation assays of a kitchen waste with an alkalinity/COD ratio of $37 \mathrm{mg} \mathrm{NaHCO}_{3} / \mathrm{g}$ $\mathrm{COD}$, the use of a granular inoculum prevented acidification for waste/inoculum ratios between 0.5 and $2.3 \mathrm{~g}$ VS/g VS. This was not achieved by a suspended sludge with a significantly lower activity, since the $\mathrm{pH}$ decreased below 5.5 for the waste/inoculum ratio of $2.3 \mathrm{~g}$ VS/g VS. In similar experiments, when a lower buffer capacity of $2 \mathrm{mg} \mathrm{NaHCO} 3 / \mathrm{g}$ COD was applied, no significant differences were obtained between the two sludges, and for waste/inoculum ratios beyond $0.5 \mathrm{~g}$ VS/g VS acidification occurred. The ratio waste/inoculum ratio was, in this case, more important than the inoculum activity. The advantage of using granular sludge was further investigated in order to define reasonable condition of waste/inoculum ratio and added alkalinity that could be applied in practice. For a waste/inoculum ratio of 1.35 , there were no significant differences between the obtained results for the biodegradability and MMPR, when the alkalinity decreased from 44 to $22 \mathrm{mg} \mathrm{NaHCO} / 3 / g$ COD. The use of granular sludge for this waste/inoculum ratio can therefore be an advisable way of preventing acidification, in the case of waste composition fluctuations.

\section{Acknowledgements}

The authors thank to FCT for the financial support given to Lúcia Neves through the project POCTI/1999/CTA/36524. 


\section{References}

[1] Kalyuzhnyi S, Veeken A, Hamelers B. Two-particle model of anaerobic solid-state fermentation. Water Sci Technol 2000;41(3):4350 .

[2] Veeken A, Hamelers B. Effect of temperature on the hydrolysis rate of selected biowaste components. Bioresour Technol 1999;69(3):249_ 55 .

[3] Gunaseelan VN. Anaerobic digestion of biomass for methane production: a review. Biomass Bioenergy 1997;13(1-2):83-114.
[4] Chynoweth DP, Turick CE, Owens JM, Jerger DE, Peck MW. Biochemical methane potential of biomass and waste feedstocks. Biomass Bioenergy 1993;5:95-111.

[5] Colleran E, Concannon F, Goldem T, Geoghegan F, Crumlish B, Killilea E, et al. Use of methanogenic activity tests to characterize anaerobic sludges, screen for anaerobic biodegradability and determine toxicity thresholds against individual anaerobic trophic groups and species. Water Sci Technol 1992;25:31-40.

[6] Standard methods for the examination of water and wastewater. 17th ed. Washington, DC: APHA, AWWA, WPCF; 1989. 